\title{
A study on selective leaching of heavy metals vs. iron from fly ash
}

\author{
Heini Elomaa ${ }^{1}\left[\right.$. Sipi Seisko ${ }^{1} \cdot$ Jenna Lehtola ${ }^{1} \cdot$ Mari Lundström $^{1}$ \\ Received: 10 December 2018 / Accepted: 26 March 2019 / Published online: 1 April 2019 \\ (c) The Author(s) 2019
}

\begin{abstract}
Incinerator plant waste streams contain underexploited metals originating from households and industrial operators. The objective was to investigate the dissolution behavior of fly ash in: 0.2-7 M HCl, 0.2-7 $\mathrm{M} \mathrm{H}_{2} \mathrm{SO}_{4}, 0.5-1 \mathrm{M}$ oxalic acid, 0.5-4 M citric acid, 0.5-7 M acetic acid, water, and ethaline, at $33^{\circ} \mathrm{C}$ during $24 \mathrm{~h}$ leaching. The capability for high metals' extraction of $\mathrm{Zn}, \mathrm{Cu}, \mathrm{Ni}, \mathrm{Pb}$, and $\mathrm{Fe}$ and management of the heavy metal $\mathrm{Pb}$ through leaching or precipitation was investigated. Selective leaching of valuable metals vs. Fe was observed. The target was to find a sustainable leaching method and provide a basis for further development of metal recovery from fly ash. The highest $\mathrm{Zn}$ extraction $(>80 \%)$ was achieved with $3 \mathrm{M} \mathrm{H}_{2} \mathrm{SO}_{4}$ and $7 \mathrm{M} \mathrm{HCl}$, which also dissolved $\mathrm{Cu}(>87 \%)$ and $\mathrm{Ni}(>65 \%)$. However, more dilute $\mathrm{HCl}, 0.2 \mathrm{M}$, was able to provide $\mathrm{Zn}, \mathrm{Cu}$, and $\mathrm{Ni}$ extractions of 43,86 , and $18 \%$, respectively. Efficient $\mathrm{Pb}$ leaching was achieved in $\mathrm{HCl}-$ complete extraction was provided by 3 and $5 \mathrm{M} \mathrm{HCl}$, whereas $\mathrm{H}_{2} \mathrm{SO}_{4}$ did not extract $\mathrm{Pb}$ due to $\mathrm{PbSO}_{4}$ formation; similarly, in oxalic acid, $\mathrm{Pb}$ precipitated as $\mathrm{PbC}_{2} \mathrm{O}_{4}$. Ethaline could extract $50 \%$ of $\mathrm{Pb}$ with high selectivity towards $\mathrm{Fe}$.
\end{abstract}

Keywords Circular economy · Waste gas purification dust · Mineral acid · Organic acid · Ethaline

\section{Introduction}

Incineration is a common way to dispose municipal solid waste (MSW) and simultaneously generate energy [1]. This waste-to-energy incineration process is being increasingly used and is a viable management strategy for treating the increasing amounts of MSW that are not recyclable [1-3]. MSW incineration (MSWI) can reduce the waste mass by $70 \%$ and waste volume by $90 \%$ [2-4]. Consequently, MSWI produces two main solid by-products, which are divided into bottom ash (BA) and fly ash (FA) [3, 4]. Any metals present in the disposed waste will end up in these fractions, which are currently notably underutilized.

Fly ash is the finer fraction collected from flue gas by air pollution control (APC) devices such as cyclones, electrostatic precipitators, fabric filters, or scrubbers. The composition of the dust is affected by the purification method used, temperature, and additives [5]. Fly ash is considered toxic waste due to the enrichment of heavy

Mari Lundström

mari.lundstrom@aalto.fi

1 Department of Chemical and Metallurgical Engineering (CMET), School of Chemical Engineering, Aalto University, Aalto, P.O. Box 12200, 00076 Espoo, Finland metals, such as $\mathrm{Pb}, \mathrm{Zn}, \mathrm{As}$, and $\mathrm{Cd}$ into this fraction during combustion. According to Jung et al. [6], approximately one-third of $\mathrm{Pb}$ and $\mathrm{Zn}$ is distributed to fly ash due to volatilization. The relative amount of chlorides can also be higher in fly ash compared to bottom ash due to the lime scrubber used in the APC system [4]. To protect the environment and ensure safety for human health, these ash fractions are subjected to different unit processes prior to landfilling. Heavy metals need to be properly cleaned from fly ash due to the risk of metals being released into the environment [7]. The main treatment technologies used for MSWI fly ash are washing, chemical stabilization, and solidification as well as thermal treatment [8]. The challenges of landfilling are that the toxic ash material is required to be deposited in specialized sites at high cost, with the risk of environmental pollution and simultaneously the possible loss of valuable metals $[9,10]$. However, it is increasingly difficult to find sites for landfills, and therefore an increasing part of the streams currently classified as waste is becoming a resource. The recovery of metals from fly ash can be considered a source of valuable metals that would otherwise be landfilled; in addition, this would result in an ash residue fraction with lower concentrations of toxic metals [9]. At the moment, according to the London Metal Exchange [11], the prices of pure $\mathrm{Cu}$, 
$\mathrm{Ni}, \mathrm{Pb}$, and $\mathrm{Zn}$ are as follows: $\mathrm{Cu} 6257 \mathrm{US} \$$, Ni 12895 US\$, Pb 1996 US\$, and Zn 2546 US\$. This indicates that for $1 \mathrm{t}$ of fly ash the value of metals is approximately 50 US dollars if counted in terms of pure metal value. Especially, nickel is a valuable battery metal with growing demand $[12,13]$, specifically for lithium ion batteries [14]. Therefore, improved Ni extraction of secondary raw materials is of vital importance. These reasons create not only an environmental but also an economic driving force to recover these metals, thus progressing toward the circular economy of metals.

Hydrometallurgical treatment of fly ash can provide new metal extraction possibilities and should be considered an alternative treatment for recovering valuable metals from fly ash. To achieve a selective and low-cost process, the lixiviant used should be carefully chosen and adapted to the properties of the ash [9]. Luo et al. [15] reviews the extraction methods of MSWI ashes, highlighting that mineral acids and alkaline solutions are effective for removal of $\mathrm{Cr}, \mathrm{Cu}, \mathrm{Zn}$ and $\mathrm{Pb}$, whereas organic acids are not as effective, even though soluble metal complexes are forming in these solutions. Mineral acids include hydrochloric acid [9, 16-18], sulfuric acid [19-21], and nitric acid [19,22], these being mostly used due to high solubility of several metal compounds at low pH [23]. Cationic leaching pattern is proposed for most of metals species, such as $\mathrm{Ca}, \mathrm{Cu}, \mathrm{Mn}, \mathrm{Zn}, \mathrm{Cd}$ and $\mathrm{Pb}$ [15]. Furthermore, organic acids have been seen as potential lixiviants for fly ash leaching, for instance, citric acid [8, 16, 24-26], oxalic acid [20, 24, 27], and acetic acid [20, 28]. Additionally, some other lixiviants such as EDTA [20,29], sodium acetate [7], sodium hydroxide [22, 29], and thiourea [29] have been investigated for stabilization of fly ash.

Fedje et al. [20] concluded that mineral acids are more effective compared to organic acids in the leaching of $\mathrm{Cu}$, $\mathrm{Zn}$, and $\mathrm{Pb}$ from MSWI fly ash. However, leaching of $\mathrm{Pb}$, which is the major toxic element in fly ash, cannot be conducted in sulfuric acid due to the formation of $\mathrm{PbSO}_{4}$ [26]. According to Huang et al. [17], hydrochloric acid appears to be a potential candidate for fly ash leaching, as $\mathrm{Pb}$ is able to complex with chloride anions as $\mathrm{PbCl}_{4}{ }^{2-}$, even though the formation of insoluble $\mathrm{PbCl}_{2}$ is also possible. Fedje et al. [20] stated that organic acids are not generally effective leaching agents for metals; however, the benefit of organic acids is their biodegradability. Nevertheless, the recovery of metals from organic acids can be challenging, similar to chelating agents [26].

A new group of lixiviants, deep eutectic solvents or molten salts, have attracted interest in metallurgical research due to their ability to leach refractory ores. The dissolution of metal oxides [30], electric arc furnace dusts [31], and selective leaching of metals from mixed metal oxides has been investigated in deep eutectic solutions [32]. Therefore, deep eutectic solvents may also be interesting and environmentally benign leachants for fly ash.

The objective of this paper is to fill the research gap by building a comparable leaching behavior map of potential lixiviants in metal rich fly ash leaching. The research contains a wide set of lixiviants $\left(\mathrm{HCl}, \mathrm{H}_{2} \mathrm{SO}_{4}, \mathrm{C}_{2} \mathrm{H}_{2} \mathrm{O}_{4}, \mathrm{C}_{6} \mathrm{H}_{8} \mathrm{O}_{7}\right.$, $\mathrm{C}_{2} \mathrm{H}_{4} \mathrm{O}_{2}$ acids, water, and the deep eutectic solvent, ethaline, i.e., choline chloride, $\mathrm{C}_{5} \mathrm{H}_{14} \mathrm{CINO}+$ ethylene glycol $\mathrm{HOCH}_{2} \mathrm{CH}_{2} \mathrm{OH}$, in a ratio of 1:2). The leaching phenomena related to main valuable and toxic metals of interest (i.e., $\mathrm{Zn}, \mathrm{Cu}, \mathrm{Ni}, \mathrm{Pb}$, and $\mathrm{Fe}$ ) were investigated, and specifically the focus was in selective leaching vs. Fe, which is the dominating and costly impurity metal in hydrometallurgical processing. Good selectivity (vs. Fe) reports directly to decrease in process costs: (1) decrease in opex, i.e., no need to Fe precipitation chemicals, (2) decrease in capex along the decrease in the required process retention time (i.e., the amount/volume of reactors) needed for Fe precipitation, (3) decrease in capex and opex as no Fe residue filter, residue washing and disposal of iron residue is needed. In the current study, also, the use of ethaline in fly as leaching was investigated for the first time. The comparable map provides new data and observations of leaching phenomena that can grant good basis for the further development of metal recovery from fly ash and thus contribute into the improved circular economy of metals.

\section{Materials and methods}

The composition of the raw material (fly ash from waste gas purification) used in this research is depicted in Table 1. The raw material was supplied by a Finnish incineration plant. The main elements of interest were $\mathrm{Zn}(1.1 \mathrm{wt} \%), \mathrm{Pb}$ $(0.8 \mathrm{wt} \%)$, and $\mathrm{Fe}(1.5 \mathrm{wt} \%)$ as well as the minor elements of $\mathrm{Cu}(0.06 \mathrm{wt} \%)$ and $\mathrm{Ni}(0.03 \mathrm{wt} \%)$. The raw material was analyzed by X-ray fluorescence (XRF), as well as by total leaching by atomic absorption spectroscopy (AAS, Varian AA240, USA) and inductively coupled plasma optical emission spectrometry ICP-OES (ICP Perkin Elmer Optima 7100 DV, USA).

Further characterization of the material was performed with an SEM-EDS (scanning electron microscope, LEO 1450 VP, Zeiss, Germany, Energy dispersive X-ray spectroscopy, Oxford Instruments INCA software). The samples were pressed into pellets using a hydraulic press (Compac, Denmark). The pellets were cast into epoxy resin for microanalysis. The SEM-EDS analysis showed that the fly ash is mostly amorphous, which is why analysis could not be conducted adequately by the SEM-EDS method. However, the SEM-EDS results also indicated that the ash particles contained at least $\mathrm{Na}, \mathrm{Mg}, \mathrm{Al}, \mathrm{Si}, \mathrm{S}, \mathrm{Cl}, \mathrm{K}, \mathrm{Ca}, \mathrm{Ti}, \mathrm{Mn}, \mathrm{Fe}$, $\mathrm{Cu}, \mathrm{Zn}$, and $\mathrm{Pb}$. 
Table 1 Chemical composition of the studied fly ash

\begin{tabular}{llllll}
\hline Metal & XRF $(\mathrm{ppm})$ & $\begin{array}{l}\text { Total dissolution } \\
\text { AAS/ICP }(\mathrm{ppm})\end{array}$ & $\begin{array}{l}\text { Total dissolution } \\
\text { ICP-OES }(\mathrm{ppm})\end{array}$ & Mean (ppm) & $\begin{array}{l}\text { Standard } \\
\text { deviation }\end{array}$ \\
\hline $\mathrm{As}$ & 1537 & 2933 & 3760 & 2743 & 917 \\
$\mathrm{Cd}$ & $<23$ & - & - & - & - \\
$\mathrm{Co}$ & $<12$ & - & - & - & - \\
$\mathrm{Cr}$ & 385 & $<50$ & 246 & 316 & 70 \\
$\mathrm{Cu}$ & 554 & 553 & 568 & 558 & 7 \\
$\mathrm{Fe}$ & - & 14,050 & 15,400 & 14,725 & 675 \\
$\mathrm{Hg}$ & $<20$ & - & - & - & - \\
$\mathrm{Ni}$ & 368 & 268 & 251 & 296 & 52 \\
$\mathrm{~Pb}$ & 8481 & 7100 & 7250 & 7610 & 619 \\
$\mathrm{~S}$ & - & - & 34,050 & - & - \\
$\mathrm{Sb}$ & 223 & 383 & 377 & 328 & 74 \\
$\mathrm{Zn}$ & 10,956 & 10,950 & 11,300 & 11,128 & 172 \\
\hline
\end{tabular}

The analysis methods used were XRF, AAS/ICP, and ICP-OES
Table 2 Chemicals used suppliers and grade

\begin{tabular}{lll}
\hline Chemical & Supplier & Grade \\
\hline $\mathrm{HCl}(37 \%)$ & Merck & Analytical grade \\
$\mathrm{H}_{2} \mathrm{SO}_{4}(95-97 \%)$ & Merck & Analytical grade \\
$\mathrm{C}_{2} \mathrm{H}_{4} \mathrm{O}_{2}(96 \%)$ & VWR & Analytical grade \\
$\mathrm{C}_{2} \mathrm{H}_{2} \mathrm{O}_{4} \cdot 2 \mathrm{H}_{2} \mathrm{O}$ & Merck & Emplura \\
$\mathrm{C}_{5} \mathrm{H}_{14} \mathrm{CINO}$ & MP Biomedicals & Cell culture reagent \\
$\mathrm{C}_{6} \mathrm{H}_{8} \mathrm{O}_{7}(99.8 \%)$ & VWR & Pharmacopoeia grade \\
$\mathrm{HOCH}_{2} \mathrm{CH}_{2} \mathrm{OH}(99.5 \%)$ & Merck & Analytical grade \\
\hline
\end{tabular}

The results presented on this paper are validated for the specific type of fly ash provided by Finnish industrial incineration plant from specific waste gas purification stage from the incineration of hazardous type of waste. The material used in this study contains similar amounts of $\mathrm{Fe}$ and $\mathrm{Pb}$ as described by Chandler et al. [33] The zinc content in this material is lower compared to values observed by Huang et al. $[17,26] \mathrm{Cu}$ and $\mathrm{Ni}$ corresponded to concentrations presented by Chandler et al. [33] The concentrations of $\mathrm{Cu}$, $\mathrm{Ni}, \mathrm{Pb}$ and $\mathrm{Zn}$ are in range of general fly ash compositions reported by Jiao et al. [34] This suggests that the leaching behavior discussed in this paper can also be adapted to other fly ashes. However, it needs to be noted that the other metals, such as $\mathrm{Na}, \mathrm{Si}$, and $\mathrm{Ca}$ can complicate the dissolution of valuable metals.

The leaching tests for fly ash were conducted at $33{ }^{\circ} \mathrm{C}$ in ambient pressure and in the absence of oxygen purging. The studied lixiviants were water, sulfuric acid, hydrochloric acid, citric acid, acetic acid, oxalic acid, and ethaline (choline chloride, $\mathrm{C}_{5} \mathrm{H}_{14} \mathrm{CINO}$ + ethylene glycol $\mathrm{HOCH}_{2} \mathrm{CH}_{2} \mathrm{OH}$, 1:2). The chemicals used and investigated concentrations are listed in Tables 2 and 3, respectively. The concentrations of $0.2-7 \mathrm{M}$ were investigated for mineral acids. The
Table 3 Studied concentrations of the lixiviants investigated

\begin{tabular}{ll}
\hline Solution & $c(\mathrm{M})$ \\
\hline $\mathrm{HCl}$ & $0.2,0.5,1,2,3,5,7$ \\
$\mathrm{H}_{2} \mathrm{SO}_{4}$ & $0.2,0.5,1,2,3,5,7$ \\
$\mathrm{C}_{2} \mathrm{H}_{2} \mathrm{O}_{4}$ & $0.5,1$ \\
$\mathrm{C}_{2} \mathrm{H}_{4} \mathrm{O}_{2}$ & $0.5,1,2,3,5,7$ \\
$\mathrm{C}_{6} \mathrm{H}_{8} \mathrm{O}_{7}$ & $0.5,1,2,3,4$ \\
Water & \\
Ethaline & 1 part $\mathrm{C}_{5} \mathrm{H}_{14} \mathrm{CINO}$ and \\
& 2 parts of 1,2-ethan- \\
& ediol \\
\hline
\end{tabular}

concentrations for organic acids were limited by the solubility of organic acids into water.

Ethaline solution was prepared by measuring one part of choline chloride, $\mathrm{C}_{5} \mathrm{H}_{14} \mathrm{CINO}$, and two parts of 1,2-ethanediol into a beaker [30]. The beaker was heated up to $80{ }^{\circ} \mathrm{C}$ and stirred with a magnetic stirrer (IKA ${ }^{\circledR}$ RT10) until the solution was clear, after which the solution was allowed to cool down.

In each test, the solid-to-liquid ratio used was $50 \mathrm{~g} / \mathrm{L}$, and mixing was conducted with a magnetic stirrer at 300 RPM for $24 \mathrm{~h}$. The $\mathrm{pH}$ and redox were measured before and after the $24 \mathrm{~h}$ leaching time using a Mettler Toledo Inlab ${ }^{\circledR}$ saturated calomel electrode (SCE) vs. platinum wire for redox potential and Hanna Instruments edge ${ }^{\circledR}$ Multiparameter $\mathrm{pH}$ Meter-HI2020 for $\mathrm{pH}$. At the end of each leaching experiment, the leach residue was filtered, dried, and the metal extractions were then calculated based on solution analysis by a commercially accredited laboratory (Labtium Oy, Espoo, Finland). Filtration was performed at room temperature under atmospheric conditions with a vacuum filter using double filter paper (Munktell, grade 10, size $\varnothing 90 \mathrm{~mm}$ ) in 
a Büchner funnel. The filtrated solution samples were analyzed by AAS and ICP-OES.

The selectivity coefficient was calculated by comparing the ratio of the dissolved elements in solution, for example $c(\mathrm{Cu}) / c(\mathrm{Fe})$. The main interest was to evaluate the selective dissolution of valuable metals compared to iron, which precipitates back into the neutralization residue of hydrometallurgical operations, if dissolved.

\section{Results}

The extraction of $\mathrm{Zn}, \mathrm{Cu}, \mathrm{Ni}, \mathrm{Pb}$, and $\mathrm{Fe}$ was investigated in all leaching tests at $T=33{ }^{\circ} \mathrm{C}$. The redox potential was measured before and after $24 \mathrm{~h}$ of leaching. The measured $\mathrm{pH}$ and redox potentials are presented in Table 4. It can be seen that, in hydrochloric acid the final $\mathrm{pH}$ varied between -1.2 and 2.9. In sulfuric acid the $\mathrm{pH}$ varied between -0.9 and 1.1, and in oxalic acid the $\mathrm{pH}$ varied between 0.6 and 0.5 after leaching. Acetic acid had the highest final $\mathrm{pH}$ values, which varied between 2.5 and 4.1. In addition, citric acid had final $\mathrm{pH}$ values of $1.3,1.8$, and 2.3 in $0.5,1$, and $2 \mathrm{M}$ solutions, respectively. In general, the mineral acids were shown to be more oxidative with redox potentials of around 400-600 mV vs. SCE, whereas for organic acids the redox potentials were between 250 and $425 \mathrm{mV}$ vs. SCE. The lowest redox potential values were measured in water, around $150 \mathrm{mV}$ vs. SCE.

\section{Extraction of $\mathrm{Zn}, \mathrm{Cu}, \mathrm{Ni}, \mathrm{Pb}$, and $\mathrm{Fe}$}

Significant amounts of $\mathrm{Zn}$ can be found in fly ash material due to the volatilization of metallic $\mathrm{Zn}$ and $\mathrm{ZnCl}_{2}$ during the incineration process, following adsorption of vaporized metals on fly ash particles [15]. In general, higher incineration temperatures support the volatilization of $\mathrm{Zn}$ and other volatile metals such as $\mathrm{Cd}, \mathrm{Pb}$, and $\mathrm{As}$ [6]. However, according to Jung et al. [6] typically only one-third of the total zinc is found in the fly ash in industrial plants, whereas the rest are present in the bottom ash fraction. This was found to be due to the predominance of non-volatile zinc phases such as zinc oxides in the raw material [35].

Elementary $\mathrm{Zn}$ is known to be acid-dissolvable $\left(E^{0}=-0.76 \mathrm{~V}\right)$, explaining the high extractions in sulfuric acid and hydrochloric acid media even at temperature $\left(T=33^{\circ} \mathrm{C}\right)$, see Fig. 1a. The highest extraction $(>80 \%)$ was achieved with $3 \mathrm{M}$ sulfuric acid and $7 \mathrm{M}$ hydrochloric acid. However, more dilute $0.5 \mathrm{M} \mathrm{H}_{2} \mathrm{SO}_{4}$ and $2 \mathrm{M} \mathrm{HCl}$ were able to provide significant $\mathrm{Zn}$ extraction of $76.9 \%$ and $76.5 \%$, respectively, and even $0.2 \mathrm{M} \mathrm{H}_{2} \mathrm{SO}_{4}$ and $\mathrm{HCl}$ were able to dissolve $>42 \%$ of $\mathrm{Zn}$. The highest $\mathrm{Zn}$ extraction in organic acids was observed in citric acid (approx. 50\%). With acetic acid, approx. $40 \%$ extraction was achieved, whereas oxalic
Table 4 Measured $\mathrm{pH}$ and redox potentials ( $\mathrm{mV}$ vs. SCE) from the solutions used in the leaching tests

\begin{tabular}{|c|c|c|c|c|c|}
\hline Solution & $c(\mathrm{M})$ & $\mathrm{pH}, t=0 \mathrm{~h}$ & $\mathrm{pH}, t=24 \mathrm{~h}$ & $\begin{array}{l}\text { Redox (mV } \\
\text { vs. SCE), } \\
t=0 \mathrm{~h}\end{array}$ & $\begin{array}{l}\text { Redox (mV } \\
\text { vs. SCE), } \\
t=24 \mathrm{~h}\end{array}$ \\
\hline \multirow[t]{7}{*}{$\mathrm{HCl}$} & 0.2 & 0.7 & 2.9 & 474 & 393 \\
\hline & 0.5 & 0.5 & 0.8 & 415 & 476 \\
\hline & 1 & 0.2 & 0.2 & 444 & 498 \\
\hline & 2 & -0.3 & -0.2 & 507 & 512 \\
\hline & 3 & -0.5 & -0.5 & 440 & 500 \\
\hline & 5 & -0.7 & -0.9 & 427 & 488 \\
\hline & 7 & -1.3 & -1.2 & 535 & 521 \\
\hline \multirow[t]{7}{*}{$\mathrm{H}_{2} \mathrm{SO}_{4}$} & 0.2 & 0.7 & 1.1 & 523 & 477 \\
\hline & 0.5 & 0.5 & 0.5 & 435 & 492 \\
\hline & 1 & 0.1 & 0.2 & 445 & 500 \\
\hline & 2 & -0.3 & -0.2 & 510 & 520 \\
\hline & 3 & -0.4 & -0.4 & 502 & 511 \\
\hline & 5 & -0.9 & -0.9 & 499 & 505 \\
\hline & 7 & -1.3 & -0.2 & 592 & 525 \\
\hline \multirow[t]{2}{*}{$\mathrm{C}_{2} \mathrm{H}_{2} \mathrm{O}_{4}$} & 0.5 & 0.8 & 0.6 & 405 & 300 \\
\hline & 1 & 0.7 & 0.5 & 419 & 263 \\
\hline \multirow[t]{6}{*}{$\mathrm{C}_{2} \mathrm{H}_{4} \mathrm{O}_{2}$} & 0.5 & 3.5 & 4.1 & 410 & 252 \\
\hline & 1 & 2.4 & 3.7 & 423 & 369 \\
\hline & 2 & 2.3 & 3.6 & 411 & 361 \\
\hline & 3 & 1.9 & 3.1 & 457 & 377 \\
\hline & 5 & 1.7 & 2.7 & 455 & 400 \\
\hline & 7 & 1.5 & 2.5 & 457 & 432 \\
\hline \multirow[t]{5}{*}{$\mathrm{C}_{6} \mathrm{H}_{8} \mathrm{O}_{7}$} & 0.5 & 1.7 & 2.3 & 435 & 285 \\
\hline & 1 & 1.4 & 1.8 & 443 & 325 \\
\hline & 2 & 0.9 & 1.3 & 529 & 403 \\
\hline & 3 & 0.6 & 0.8 & 449 & 428 \\
\hline & 4 & 0.2 & 0.2 & 512 & 425 \\
\hline $\mathrm{H}_{2} \mathrm{O}$ & - & 6.8 & 7 & - & 149 \\
\hline $\mathrm{H}_{2} \mathrm{O}$ & - & 7.8 & 7 & - & 154 \\
\hline
\end{tabular}

The times of measurements were at $0 \mathrm{~h}$ and $24 \mathrm{~h}$

acid realized an extraction of below $20 \%$. The results also showed $20 \%$ extraction of $\mathrm{Zn}$ in ethaline; however, a remarkable observation is that water alone was able to dissolve almost $13 \%$ of $\mathrm{Zn}$, see Fig. $1 \mathrm{~b}$. This shows the reactive nature of the investigated fly ash, requiring chemical stabilization even when in contact with water.

Although the amount of $\mathrm{Cu}$ in the fly ash is 1 decade lower compared to $\mathrm{Zn}$, the economic value of copper drives its recovery. The study showed $\mathrm{Cu}$ extraction $>80 \%$ being achievable in all investigated $\mathrm{HCl}$ and $\mathrm{H}_{2} \mathrm{SO}_{4}$ concentrations (0.2-7 M), Fig. 2a. Additionally, citric acid (0.5, 1 and $2 \mathrm{M}$ ) was able to extract $>80 \%$ of $\mathrm{Cu}$ into the solution and also in acetic acid, approximately $70 \%$ of $\mathrm{Cu}$ was extracted in all studied concentrations. Oxalic acid did not provide equally high extractions, having $\mathrm{Cu}$ yield of only $25 \%$ into the solution. 

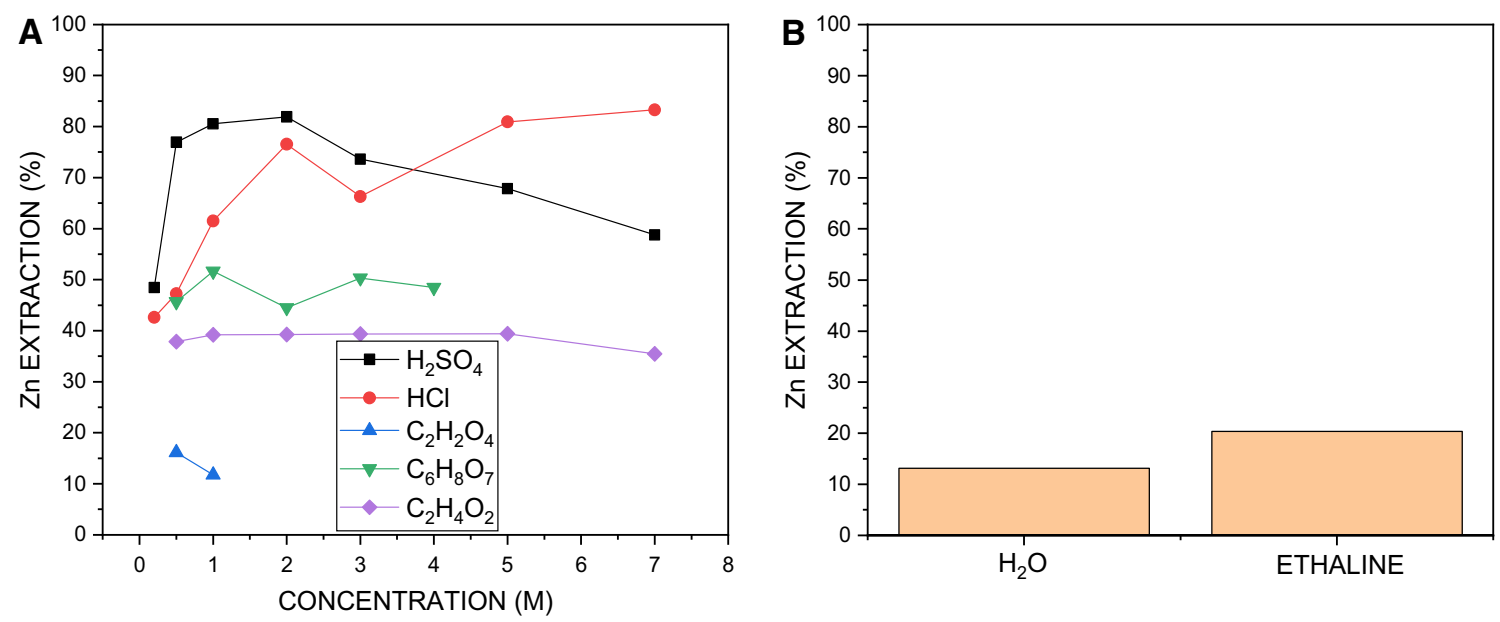

Fig. 1 Extraction of $\mathrm{Zn}$ in a hydrochloric, sulfuric, oxalic, citric, and acetic acids and $\mathbf{b}$ in water and ethaline at $33{ }^{\circ} \mathrm{C}$
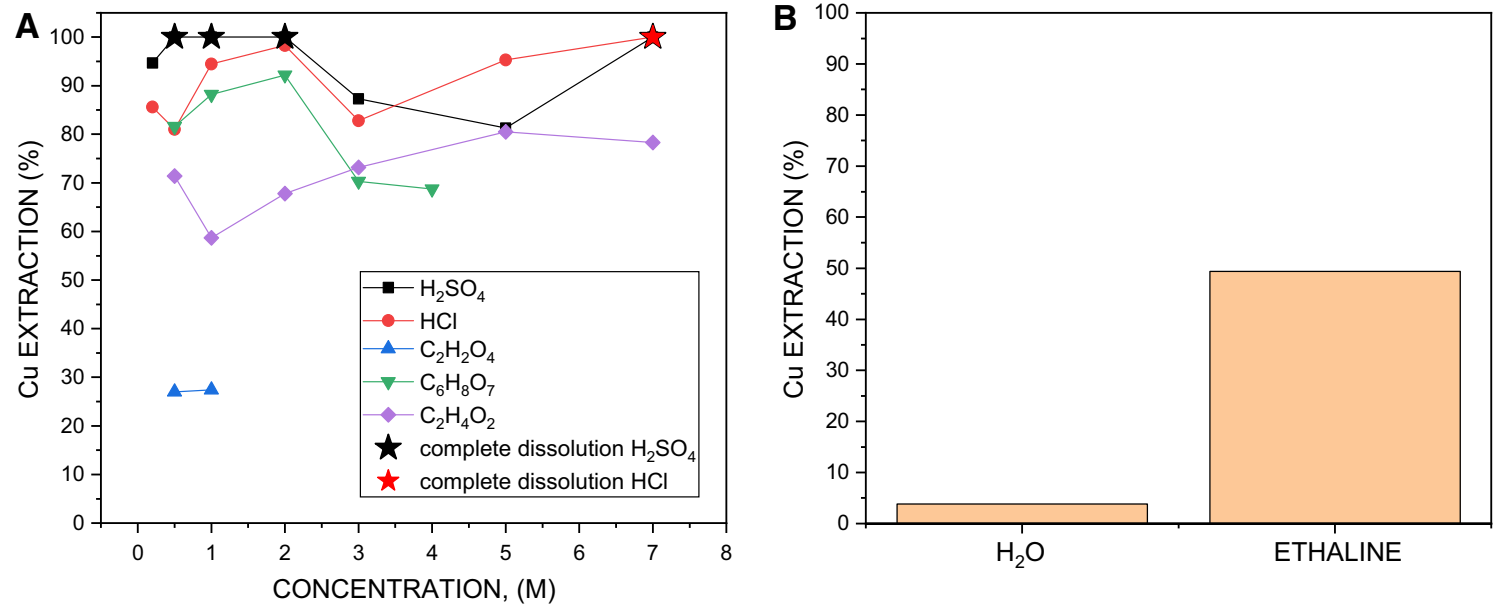

Fig. 2 Extraction of $\mathrm{Cu}$ into a hydrochloric, sulfuric, oxalic, acetic, and citric acids and $\mathbf{b}$ in water and ethaline at $33^{\circ} \mathrm{C}$

With ethaline, almost $50 \%$ copper extraction could be achieved at $33{ }^{\circ} \mathrm{C}$. The kinetics of $\mathrm{Cu}^{+} / \mathrm{Cu}^{2+}$ redox couple has been investigated in ethaline by Lloyd et al. [36] and the copper is known to dissolve in ethaline forming chloride complexes. However, even water dissolved minor (3-4\%) of $\mathrm{Cu}$, Fig. 2b. The results suggest that $\mathrm{Cu}$ is in easily dissolvable form in the fly ash, as nearly complete copper extraction can be achieved even at the lowest investigated mineral acid concentrations $(0.2 \mathrm{M})$.

The fly ash raw material investigated here contained a minor amount of $\mathrm{Ni}(296 \mathrm{ppm})$. The results show that with mineral acids at $33{ }^{\circ} \mathrm{C}$, almost $100 \%$ extraction of $\mathrm{Ni}$ could be achieved. However, the dissolution required high acidity to reach maximum extraction ( $3 \mathrm{M} \mathrm{HCl}$ or $5 \mathrm{M} \mathrm{H}_{2} \mathrm{SO}_{4}$ ), see Fig. 3a. Organic acids were not able to leach $\mathrm{Ni}$ as efficiently with the highest extractions $33 \%$ with $3 \mathrm{M}$ citric acid, $25 \%$ with $3 \mathrm{M}$ acetic acid, and $14 \%$ with $0.5 \mathrm{M}$ oxalic acid.
Again, water was shown to dissolve a notable amount of nickel (6\%), whereas ethaline dissolved only 4\%, see Fig. 3b.

$\mathrm{Pb}$ volatilizes at as low as $430{ }^{\circ} \mathrm{C}$, thus being the main toxic metal in fly ash [35]. It is in the interest of incinerator plants to remove $\mathrm{Pb}$ to produce safely disposable leaching residue. Figure $4 \mathrm{a}$ presents the extraction of $\mathrm{Pb}$ in the solutions under study. It is evident that increasing acid concentration increases $\mathrm{Pb}$ extraction-the exceptions being sulfuric and oxalic acid. Sulfuric acid supports the formation of insoluble lead sulfate [37, 38]. Moreover, oxalic acid did not leach $\mathrm{Pb}$. According to Fedje et al. [20], $\mathrm{Pb}$ precipitates as $\mathrm{PbC}_{2} \mathrm{O}_{4}$ in oxalic acid. This phenomenon has also been found in other studies [16, 25]. This allows other metals to be dissolved selectively vs. $\mathrm{Pb}$ in sulfuric acid and oxalic acid; however, in that case secondary leaching or a stabilization process is required for $\mathrm{Pb}$-enriched residue. The solution providing complete extraction of $\mathrm{Pb}$ was $\mathrm{HCl}(3 \mathrm{M})$, 

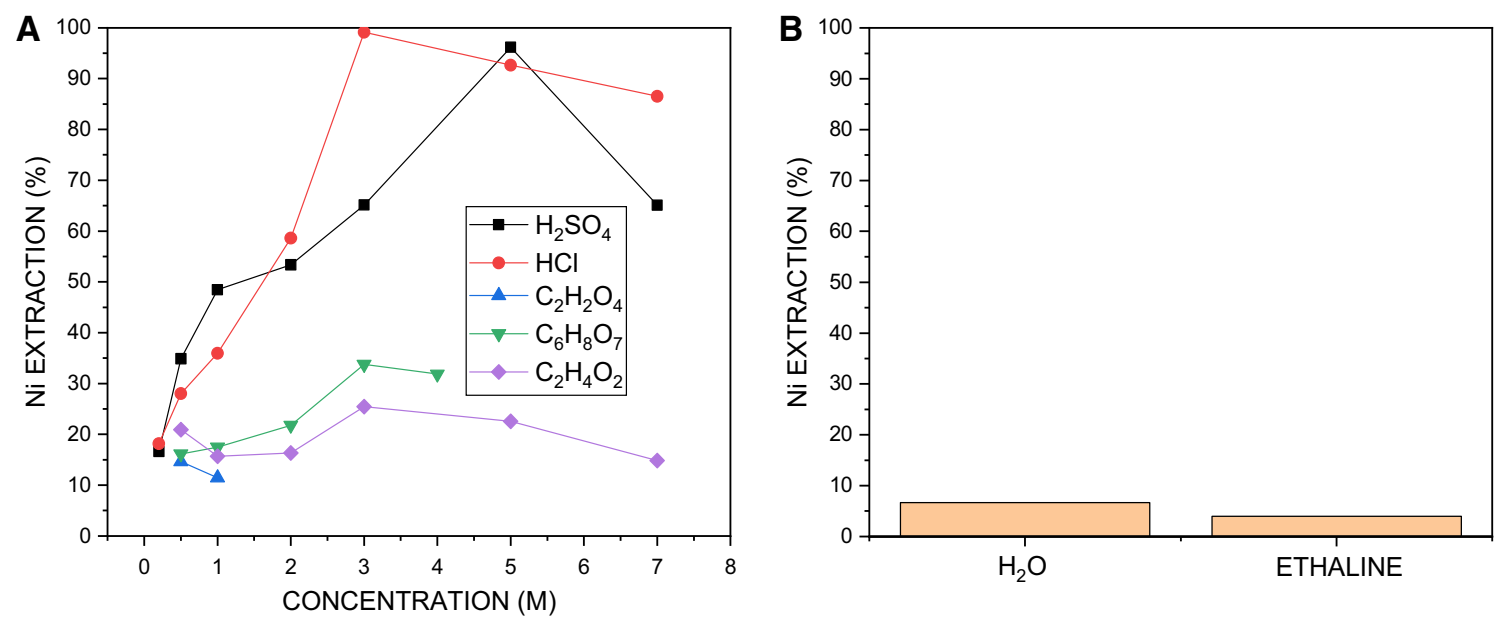

Fig. 3 Extraction of $\mathrm{Ni}$ in $\mathbf{a}$ hydrochloric, sulfuric, oxalic, citric, and acetic acids and $\mathbf{b}$ in water and ethaline at $33^{\circ} \mathrm{C}$
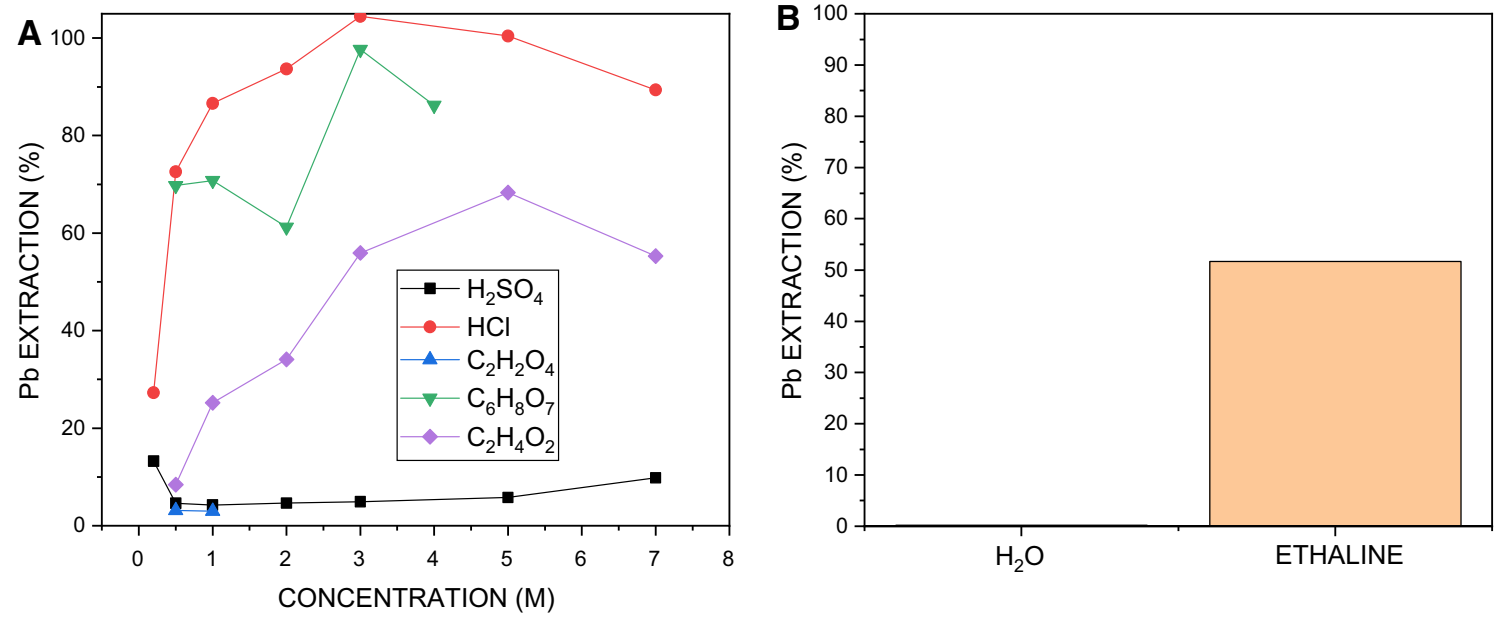

Fig. 4 Extraction of $\mathrm{Pb} \mathbf{a}$ in hydrochloric, sulfuric, oxalic, citric, and acetic acids and $\mathbf{b}$ in water and ethaline at $33{ }^{\circ} \mathrm{C}$

but all the investigated $\mathrm{HCl}$ concentrations provided $>70 \%$ extraction, with the exception of the $0.2 \mathrm{M}$ solution. In addition, $3 \mathrm{M}$ citric acid was able to dissolve $98 \%$ of $\mathrm{Pb}$. Gargul et al. [39] describe a similar trend of $\mathrm{Pb}$ extraction at $25^{\circ} \mathrm{C}$, in which the extraction first increases and then decreases at high citric acid concentration. Acetic acid also showed increasing extraction with increasing acidity, the highest extraction of $65 \%$ being achieved at $5 \mathrm{M}$ acetic acid. Figure $4 \mathrm{~b}$ presents the extraction of $\mathrm{Pb}$ in water and ethaline. In contrast to $\mathrm{Zn}, \mathrm{Cu}$, and $\mathrm{Ni}$, water could not dissolve $\mathrm{Pb}$ at all. Ethaline was shown to dissolve as much as $50 \%$ of $\mathrm{Pb}$.

The extraction of $\mathrm{Fe}$ is known to be a very $\mathrm{pH}$-dependent phenomenon. In general, mineral acids were shown to result in lower final $\mathrm{pH}$ values compared to organic acids, see Fig. 5a. The current study showed that Fe extraction in hydrochloric and sulfuric acids increased with an increase in acid concentration. With sulfuric acid, the extraction of
Fe was constant (60\%) with an acidity of $2-5 \mathrm{M}$ (measured $\mathrm{pH}$ between -0.2 and -0.9 ) but increased up to $80 \%$ in $7 \mathrm{M}$. Hydrochloric acid resulted in quite a similar Fe extraction pattern, see Fig. 5b. Selective leaching of other metals vs. iron was shown to be possible in $0.2 \mathrm{M} \mathrm{HCl}$, as the final $\mathrm{pH}$ of 2.9 indicates that iron had precipitated into the leach residue.

Of the organic acids, the highest Fe extraction (>60\%) was achieved with oxalic acid, having the lowest final $\mathrm{pH}$ of the investigated organic acids. In oxalic acid iron can dissolve as soluble $\mathrm{FeC}_{2} \mathrm{O}_{4}$ [25, 40]. In contrast, citric acid was able to leach only $15-20 \%$ of iron in the measured $\mathrm{pH}$ range of $0.2-2.3$. Additionally, with acetic acid, less than $2 \%$ of iron was leached, with the final $\mathrm{pH}$ value (2.5-4.1) supporting iron precipitation as hydroxide. Fe did not dissolve into ethaline or water-extraction being $0.08 \%$ in water and $0.5 \%$ in ethaline. 

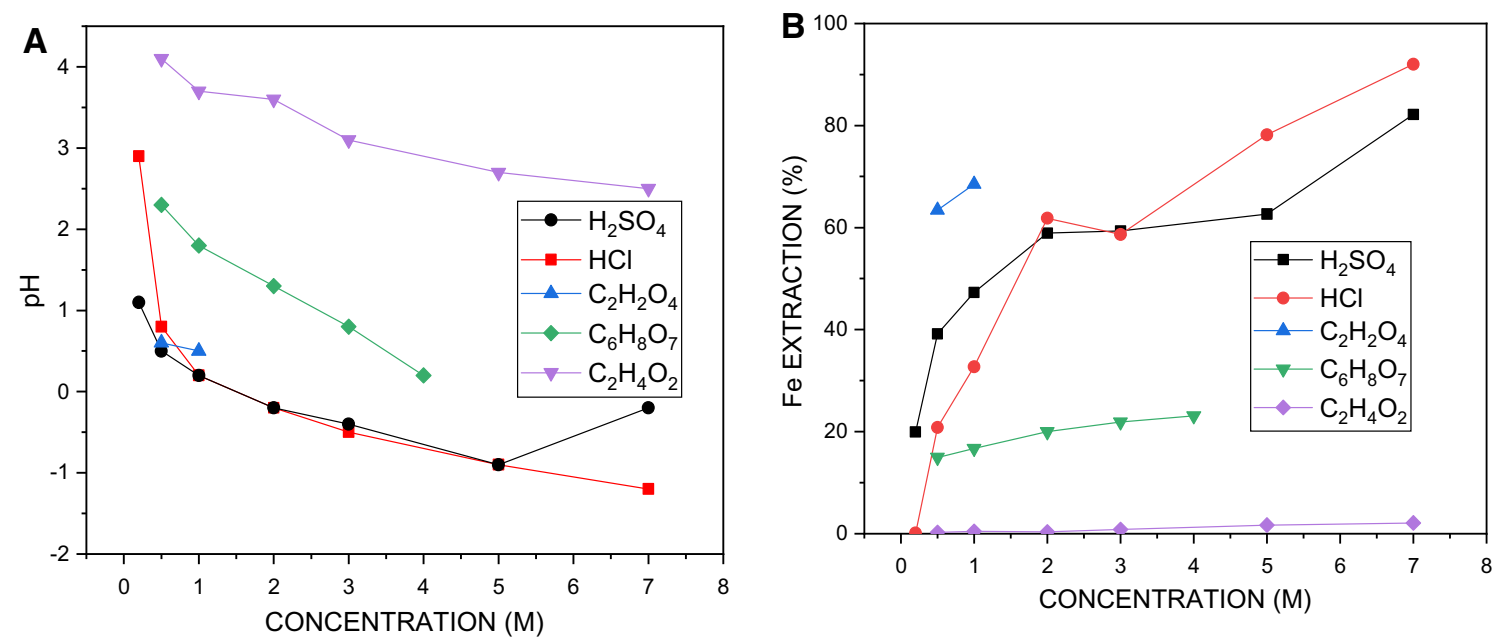

Fig. 5 Extraction of Fe into a hydrochloric, sulfuric, oxalic, citric, and acetic acids and the measured final $\mathrm{pH}(\mathbf{b}) \mathrm{values}$ at $T=33{ }^{\circ} \mathrm{C}$ in the $24 \mathrm{~h}$ leaching tests

\section{Selective leaching of metals}

In hydrometallurgical processing, there are typically several reactors and leaching stages which not only assure time for chemical reactions to occur but also enable tailoring of the process conditions for feasible metal recovery. Typically, iron is dissolved in the first acid leaching stage along the valuable metals, whereas neutralization/precipitation chemicals are added and $\mathrm{pH}$ increased in the next stage to remove iron [41]. In state-of-art technologies, iron is removed from hydrometallurgical processing circuits as hematite, goethite, and jarosites and disposed at waste ponds [42]. Selective leaching of valuable or other target metals vs. Fe can bring both economic and environmental benefits, as iron dissolution, chemical consumption and waste formation can be minimized. This highlights the importance of selective valuable (or toxic) metals dissolution. In the investigated raw material, $\mathrm{Zn}$ is the dominating valuable base metal whereas $\mathrm{Fe}$ cannot be recovered from the solution as a valuable product.

Figure $6 \mathrm{a}$ presents the $\mathrm{Zn}$ selectivity factor calculated based on soluble $\mathrm{Zn}$ and $\mathrm{Fe}$ concentrations $(\mathrm{mg} / \mathrm{L})$. The results show that the selectivity ratio between $\mathrm{Zn}$ and Fe was remarkably good with the $0.2 \mathrm{M} \mathrm{HCl}$ solution, with a value of 247. In addition, acetic acid $(0.5 \mathrm{M})$ and water showed high selectivity between $\mathrm{Zn}$ and $\mathrm{Fe}(>100)$. Also, ethaline showed some selectivity between $\mathrm{Zn}$ and $\mathrm{Fe}$ (22-30). However, the final extraction of $\mathrm{Zn}$ in these solutions was only $42 \%$ in $0.2 \mathrm{M} \mathrm{HCl}, 37 \%$ in $0.5 \mathrm{M}$ acetic acid, $13 \%$ in water, and $20 \%$ in ethaline. The same solutions were also shown to provide good selectivity regarding copper dissolution: $0.2 \mathrm{M} \mathrm{HCl}$ and $0.5 \mathrm{M}$ acetic acid provided the highest $\mathrm{Cu} / \mathrm{Fe}$ ratio (25 and 28 ) as well as high extractions ( 85 and $70 \%$, respectively), see Fig. 6 b. The $\mathrm{Ni}$ content (296 ppm) in the raw material was half that of copper. However, none of the investigated solutions provided good selectivity between Ni and Fe, see Fig. 6c. Minor selectivity of $\mathrm{Ni}$ vs. $\mathrm{Fe}$ was achieved in $0.2 \mathrm{M} \mathrm{HCl}$ (2.3), $0.5 \mathrm{M}$ acetic acid (1.5), and water (1.3), with corresponding Ni extractions of $16 \%, 20 \%$, and $6 \%$, see Fig. $6 c$.

Selective leaching of $\mathrm{Pb}$ vs. $\mathrm{Fe}$ was investigated as a possibility for removing lead selectively from fly ash raw material. Figure $6 \mathrm{~d}$ presents the selectivity factor of $\mathrm{Pb}$ and $\mathrm{Fe}$ in all the studied conditions. It can be seen that $0.2 \mathrm{M} \mathrm{HCl}$ shows superior (>100) selectivity, but $2 \mathrm{M}$ acetic acid (46) and ethaline (42) can also provide high selectivity between $\mathrm{Pb}$ and $\mathrm{Fe}$, with the corresponding extractions being $27.3 \%$, $34.1 \%$, and $51.7 \%$ for $\mathrm{Pb}$. In addition, the selectivity of $\mathrm{Pb}$ toward valuable metals is presented in Fig. 6e, to observe whether toxic $\mathrm{Pb}$ can be removed from fly ash material prior to valuable metal recovery. The results suggest some selectivity by ethaline (selectivity factor 1.45), the extraction being 50\%. However, all the selectivity factors in Fig. $6 \mathrm{~d}$ are low compared to the selectivity factors calculated for $\mathrm{Zn}, \mathrm{Pb}$, and $\mathrm{Ni}$ toward $\mathrm{Fe}$. This suggests that $\mathrm{Pb}$ can be dissolved selectively vs. Fe, although not toward the other valuable metals of interest (i.e., $\mathrm{Zn}, \mathrm{Cu}, \mathrm{Ni}$ ). This highlights the importance of solution purification-as the results suggest that the conditions allowing $\mathrm{Pb}$ dissolution also support the dissolution of $\mathrm{Zn}, \mathrm{Cu}$, and Ni. However, sulfuric acid provides a medium that supports the separation of $\mathrm{Pb}$ over valuable metals by dissolving the latter and leaving $\mathrm{Pb}$ in the leach residue as precipitated lead sulfate (Fig. 4a).

\section{Conclusions}

The leaching of $\mathrm{Cu}, \mathrm{Fe}, \mathrm{Ni}, \mathrm{Pb}$, and $\mathrm{Zn}$ from fly ash using a variety of lixiviants at a constant temperature of $33^{\circ} \mathrm{C}$ was investigated to observe the leaching behavior of various 

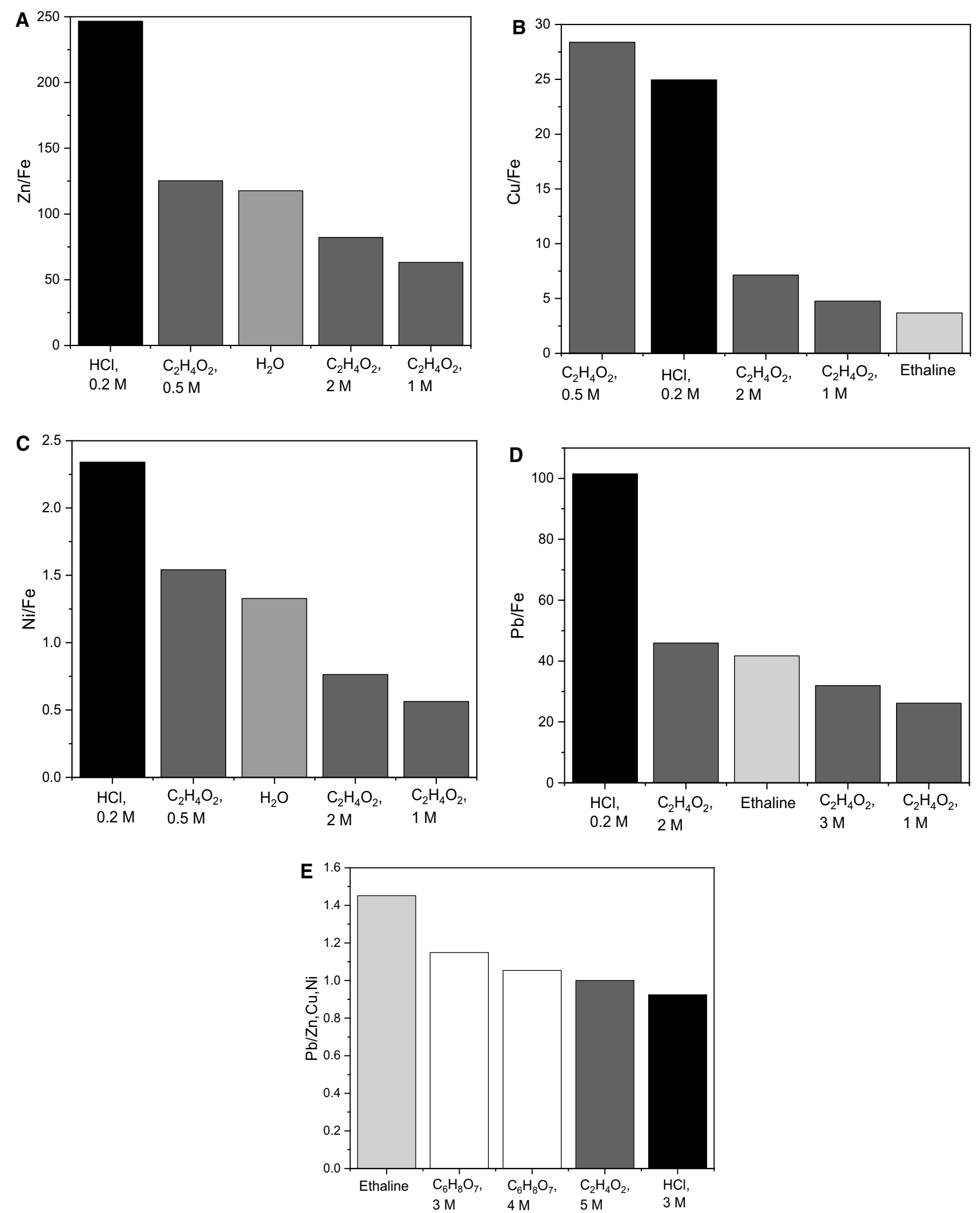

Fig. 6 The five best selectivity factors of $\mathrm{Zn}, \mathrm{Ni}$, and $\mathrm{Pb}$ toward $\mathrm{Fe}(\mathbf{a}, \mathbf{b}, \mathbf{c}, \mathbf{d})$ and the five best selectivity factors of $\mathrm{Pb}$ toward valuable metals $\mathrm{Zn}, \mathrm{Cu}$, and $\mathrm{Ni}(\mathbf{e})$ 
valuable, impure, and minor metals present in the ash. This study was performed to find strategies for future metal recovery from the investigated metal-rich fly ash fraction, which is produced globally in increasing amounts [43] and will require valorization or stabilization to make the process sustainable. The dissolution of metals from the ash residue in the environment is an issue to be addressed; further, the metals contained in the ash fractions also have financial value. In terms of the particular fly ash studied, the following conclusions can be deduced:

- The highest extraction of valuable metals in general was achieved with $\mathrm{HCl}$ and $\mathrm{H}_{2} \mathrm{SO}_{4}$. The highest $\mathrm{Zn}$ extraction $(>80 \%)$ was achieved with $3 \mathrm{M} \mathrm{H}_{2} \mathrm{SO}_{4}$ and $7 \mathrm{M} \mathrm{HCl}$. These conditions dissolved $>87 \%$ of $\mathrm{Cu}$ and $>65 \%$ of $\mathrm{Ni}$.

- The best leaching conditions for $\mathrm{Ni}$ were obtained in high-acidity mineral acids, i.e., $3 \mathrm{M} \mathrm{HCl}$ and $5 \mathrm{M} \mathrm{H}_{2} \mathrm{SO}_{4}$.

- Organic acids did not leach metals as effectively as mineral acids. In acetic acid, $\mathrm{C}_{2} \mathrm{H}_{4} \mathrm{O}_{2}, \mathrm{Zn}$ extraction was $35-39 \%$ at all studied concentrations. More than $70 \%$ extraction of $\mathrm{Cu}$ could be achieved at higher acetic acid concentrations of 3,5 , and $7 \mathrm{M}$. However, Ni extraction remained low $(<25 \%)$. Citric acid extracted around $45-50 \%$ of $\mathrm{Zn}$ and $>60 \%$ of $\mathrm{Cu}$, whereas oxalic acid $\left(\mathrm{C}_{2} \mathrm{H}_{2} \mathrm{O}_{4}\right)$ resulted in poor $\mathrm{Zn}, \mathrm{Cu}$, and $\mathrm{Ni}$ metal extractions $(<30 \%)$.

- Ethaline displayed the capability of dissolving $\mathrm{Zn}$ (20\%), $\mathrm{Cu}(49 \%)$, and $\mathrm{Pb}(50 \%)$; however, no $\mathrm{Ni}$ or $\mathrm{Fe}$ was dissolved in the ethaline.

- The best conditions for $\mathrm{Pb}$ leaching were achieved in $\mathrm{HCl}$ and complete extraction was provided by 3 and $5 \mathrm{M} \mathrm{HCl}$, but also more dilute concentrations, $0.5,1$, and $2 \mathrm{M}$ of $\mathrm{HCl}$ were readily able to dissolve over $70 \%$ of $\mathrm{Pb}$.

- Ethaline leaching of $\mathrm{Pb}$ displayed high selectivity toward Fe (41.7) and only minor selectivity toward the valuable metals $\mathrm{Zn} / \mathrm{Cu} / \mathrm{Ni}$ (1.5). Ethaline provided an advantage by not dissolving iron, although the extraction of valuable metal extractions was not as high compared to $\mathrm{HCl}$.

- When considering high $\mathrm{Cu}$ extraction, high $\mathrm{Zn}$ extraction, and good selectivity vs. iron, $0.2 \mathrm{M} \mathrm{HCl}$ showed the best selectivity to recover valuable metals $(86 \%$ of $\mathrm{Cu}, 43 \%$ of $\mathrm{Zn}$ ) without the leaching of Fe. This is a significant finding, as no aggressive solution was required for the extraction process.

Acknowledgements Open access funding provided by Aalto University. The financial support of Fortum Oy is greatly appreciated. The CMEco (Circular Metal Ecosystem, Business Finland, Tekes, Grant number 7405/31/2016) project and Clic Innovation Oy financed this work as part of the Material Values Chains, ARVI project. This work was supported by "RawMatTERS Finland Infrastructure" (RAMI) at
Aalto University (Academy of Finland). The provider of the raw material is also greatly acknowledged by the authors.

Open Access This article is distributed under the terms of the Creative Commons Attribution 4.0 International License (http://creativeco mmons.org/licenses/by/4.0/), which permits unrestricted use, distribution, and reproduction in any medium, provided you give appropriate credit to the original author(s) and the source, provide a link to the Creative Commons license, and indicate if changes were made.

\section{References}

1. Ferreira C, Ribeiro A, Ottosen L (2003) Possible applications for municipal solid waste fly ash. J Hazard Mater 96(2-3):201-216

2. Eighmy TT, Eusden JD, Krzanowski JE, Domingo DS, Staempfli D, Martin JR, Erickson PM (1995) Comprehensive approach toward understanding element speciation and leaching behavior in municipal solid waste incineration electrostatic precipitator ash. Environ Sci Technol 29(3):629-646

3. Ginés O, Chimenos JM, Vizcarro A, Formosa J, Rosell JR (2009) Combined use of MSWI bottom ash and fly ash as aggregate in concrete formulation: environmental and mechanical considerations. J Hazard Mater 169(1-3):643-650

4. Lam CH, Ip AW, Barford JP, McKay G (2010) Use of incineration MSW ash: a review. Sustainability 2(7):1943-1968

5. Kaartinen T, Laine-Ylijoki J, Wahlström M (2007) Jätteen termisen käsittelyn tuhkien ja kuonien käsittely-ja sijoitusmahdollisuudet. VTT tiedotteita, 2411

6. Jung CH, Matsuto T, Tanaka N, Okada T (2004) Metal distribution in incineration residues of municipal solid waste (MSW) in Japan. Waste Manag 24(4):381-391

7. Liu F, Liu J, Yu Q, Jin Y, Nie Y (2005) Leaching characteristics of heavy metals in municipal solid waste incinerator fly ash. $J$ Environ Sci Health 40(10):1975-1985

8. Wang H, Fan X, Wang YN, Li W, Sun Y, Zhan M, Wu G (2018) Comparative leaching of six toxic metals from raw and chemically stabilized MSWI fly ash using citric acid. J Environ Manag 208:15-23

9. Tang J, Steenari B (2016) Leaching optimization of municipal solid waste incineration ash for resource recovery: a case study of $\mathrm{Cu}, \mathrm{Zn}, \mathrm{Pb}$ and $\mathrm{Cd}$. Waste Manag 48:315-322

10. Funari V, Mäkinen J, Salminen J, Braga R, Dinelli E, Revitzer H (2017) Metal removal from municipal solid waste incineration fly ash: a comparison between chemical leaching and bioleaching. Waste Manag 60:397-406

11. The London Metal Exchange. Updated 2018. https://www.lme. com/. Accessed 27 Sept 2018

12. Ovshinsky SR, Fetcenko MA, Ross J (1993) A nickel metal hydride battery for electric vehicles. Science 260(5105):176-181

13. Dhar SK, Ovshinsky SR, Gifford PR, Corrigan DA, Fetcenko MA, Venkatesan S (1997) Nickel/metal hydride technology for consumer and electric vehicle batteries-a review and up-date. $\mathrm{J}$ Power Sources 65(1-2):1-7

14. Yoshio M, Brodd RJ, Kozawa A (2009) Lithium-ion batteries, vol 1. Springer, New York

15. Luo H, Cheng Y, He D, Yang E (2019) Review of leaching behavior of municipal solid waste incineration (MSWI) ash. Sci Total Environ 668:90-103

16. Zhang F, Itoh H (2006) Extraction of metals from municipal solid waste incinerator fly ash by hydrothermal process. J Hazard Mater 136(3):663-670

17. Huang K, Inoue K, Harada H, Kawakita H, Keisuke O (2011) Leaching behavior of heavy metals with hydrochloric acid from 
fly ash generated in municipal waste incineration plants. Trans Nonferrous Met Soc China 21(6):1422-1427

18. Weibel G, Eggenberger U, Kulik DA, Hummel W, Schlumberger S, Klink W, Fisch M, Mäder UK (2018) Extraction of heavy metals from MSWI fly ash using hydrochloric acid and sodium chloride solution. Waste Manag 76:457-471

19. Nagib S, Inoue K (2000) Recovery of lead and zinc from fly ash generated from municipal incineration plants by means of acid and/or alkaline leaching. Hydrometallurgy 56(3):269-292

20. Fedje KK, Ekberg C, Skarnemark G, Steenari B (2010) Removal of hazardous metals from MSW fly ash—an evaluation of ash leaching methods. J Hazard Mater 173(1-3):310-317

21. Zhang HY, Ma GX (2013) Leaching of heavy metals from municipal solid waste incineration (MSWI) fly ash using sulfuric acid. Appl Mech Mater 249-250:922-926

22. Okada T, Tojo Y, Tanaka N, Matsuto T (2007) Recovery of zinc and lead from fly ash from ash-melting and gasification-melting processes of MSW - comparison and applicability of chemical leaching methods. Waste Manag 27(1):69-80

23. Jadhav UU, Hocheng H (2012) A review of recovery of metals from industrial waste. J Achiev Mater Manuf Eng 54(2):159-167

24. Nugteren HW, Janssen-Jurkovicová M, Scarlett B (2001) Improvement of environmental quality of coal fly ash by applying forced leaching. Fuel 80(6):873-877

25. Wu H, Ting Y (2006) Metal extraction from municipal solid waste (MSW) incinerator fly ash-chemical leaching and fungal bioleaching. Enzyme Microb Technol 38(6):839-847

26. Huang K, Inoue K, Harada H, Kawakita H, Ohto K (2011) Leaching of heavy metals by citric acid from fly ash generated in municipal waste incineration plants. J Mater Cycles Waste Manag 13(2):118-126

27. Ettler V, Vrtišková R, Mihaljevič M, Šebek O, Grygar T, Drahota P (2009) Cadmium, lead and zinc leaching from smelter fly ash in simple organic acids-simulators of rhizospheric soil solutions. J Hazard Mater 170(2-3):1264-1268

28. Fuoco R, Ceccarini A, Tassone P, Wei Y, Brongo A, Francesconi $S$ (2005) Innovative stabilization/solidification processes of fly ash from an incinerator plant of urban solid waste. Microchem J 79(1-2):29-35

29. Youcai Z, Lijie S, Guojian L (2002) Chemical stabilization of MSW incinerator fly ashes. J Hazard Mater 95(1-2):47-63

30. Abbott AP, Boothby D, Capper G, Davies DL, Rasheed RK (2004) Deep eutectic solvents formed between choline chloride and carboxylic acids: versatile alternatives to ionic liquids. J Am Chem Soc 126(29):9142-9147
31. Abbott AP, Capper G, Davies DL, Rasheed RK, Shikotra P (2005) Selective extraction of metals from mixed oxide matrixes using choline-based ionic liquids. Inorg Chem 44(19):6497-6499

32. Abbott AP, Collins J, Dalrymple I et al (2009) Processing of electric arc furnace dust using deep eutectic solvents. Aust J Chem 62(4):341-347

33. Chandler AJ, Eighmy TT, Hartlén J, Hjelmar O, Kosson DS, Sawell SE, van der Sloot HA, Vehlow J (1997) Municipal solid waste incinerator residues, vol 67. Elsevier, Amsterdam

34. Jiao F, Zhang L, Dong Z, Namioka T, Yamada N, Ninomiya Y (2016) Study on the species of heavy metals in MSW incineration fly ash and their leaching behavior. Fuel Process Technol 152:108-115

35. Verhulst D, Buekens A, Spencer PJ, Eriksson G (1995) Thermodynamic behavior of metal chlorides and sulfates under the conditions of incineration furnaces. Environ Sci Technol 30(1):50-56

36. Lloyd D, Vainikka T, Murtomäki L, Kontturi K, Ahlberg E (2011) The kinetics of the $\mathrm{Cu}^{2+} / \mathrm{Cu}^{+}$redox couple in deep eutectic solvents. Electrochim Acta 56(14):4942-4948

37. Craig DN, Vinal GW (1939) Solubility of lead sulfate in solutions of sulfuric acid, determined by dithizone with a photronic cell. J Res Natl Bur Stand 22:55-70

38. Kolthoff IM, Perlich RW, Weiblen D (1942) The solubility of lead sulfate and of lead oxalate in various media. J Phys Chem 46(5):561-570

39. Gargul K, Boryczko B, Bukowska A, Jarosz P, Małecki S (2019) Leaching of lead and copper from flash smelting slag by citric acid. Arch Civ Mech Eng 19(3):648-656

40. Burgstaller W, Schinner F (1993) Leaching of metals with fungi. J Biotechnol 27(2):91-116

41. Hayes P (1993) Process principles in minerals and materials production. Hayes Publishing Company, Brisbane

42. Chen TT, Cabri LJ (1986) Mineralogical overview of iron control in hydrometallurgical processing. Iron control in hydrometallurgy. Ellis Horwood, England, pp 19-55

43. Brown TJ, Idoine NE, Raycraft ER, Shaw RA, Hobbs SF, Everett P, Deady EA, Bide T (2018) World mineral production 2012-16. British Geological Survey, Nottinhham, p 87 (World mineral statistics)

Publisher's Note Springer Nature remains neutral with regard to jurisdictional claims in published maps and institutional affiliations. 